\title{
A battle of languages: Spirit possession and changing linguistic ideologies in a Sepik society, Papua New Guinea
}

\author{
Darja Hoenigman \\ The Australian National University
}

\begin{abstract}
In October 2009, a dramatic event shook the existing sociolinguistic setting in Kanjimei village in East Sepik Province of Papua New Guinea. Possessed by a Christian spirit, a woman harshly reproached the most important village leaders. The ensuing verbal fight between 'the spirit' and the village prayer leader became a battle of languages: the Christian spirit spoke the community's native language, Awiakay, overpowering those in authority, who are the most frequent users of the national lingua franca Tok Pisin. As it was believed that it was the spirit of the Virgin Mary who channelled herself through the possessed woman, it was legitimate for people to discuss her words. The spirit possession thus enabled the otherwise condemned social practices: gossip and public criticism, which have the power of changing existing power relations in the village. The analysis of this event shows the complexity behind the ever-changing linguistic ideologies.
\end{abstract}

Keywords: spirit possession, code-switching, Papua New Guinea

\section{INTRODUCTION}

Building on Silverstein's (1979) pioneering work, Rumsey (1990: 346) defines linguistic ideology as 'shared bodies of common sense notions about the nature of language in the world'. These always exhibit cultural variation, in part because they are not only about language (Woolard \& Schieffelin 1994: 56), but are linked to notions of personhood, identity, gender, agency, power, and morality. As each of these culturally and historically specific notions is in a state of continual flux, linguistic ideologies are also constantly prone to change.

Looking at linguistic ideology through the prism of processes of language contact and vice versa, Makihara and Schieffelin (2007) observe that scholars often do not adequately notice and document the 'moments of choice, compromise, adjustment or even outright opposition on the part of the local community members facing introduced ideas and actions' (2007: 16). They argue that '[i]n such encounters, not only are the imposed ideas taken under consideration, but traditional ones may be re-evaluated and lead to syncretic cultural or linguistic forms' (2007: 16). This article examines one such moment. It reports on a dramatic spirit-possession event in 2009 that represented a significant change in the existing sociolinguistic 
landscape of Kanjimei village in East Sepik Province of Papua New Guinea. It thus adds to the existing pool of linguistic anthropological studies of events as they unfold (e.g. Merlan \& Rumsey 1986, 1991; Duranti 1992; Kulick 1992b, 1993; Robbins 2007). Rather than suggesting that the change in Awiakay linguistic ideology is sudden (and suddenly revealed), the event analysis in this article shows change in progress.

\section{MULTILINGUALISM, CHARISMATIC CHRISTIANITY AND IDEAS OF GEOPOLITICAL INFERIORITY IN KANJIMEI}

Before presenting and analysing the spirit-possession event, I will introduce the broad sociolinguistic situation in Kanjimei and the recent religious and economic history of the Awiakay community. These conditions are important for understanding what happened in the discourse event that will be discussed in the rest of the article.

The Awiakay are a largely endogamous community of about three hundred people living in Kanjimei village in the lowland rainforest of the Sepik River's southern flood plain. They subsist mainly by sago processing, hunting, fishing and gathering. People often say in the lingua franca Tok Pisin, mipela las ples bilong bus, 'we're the last place in the bush'. 'Awiakay often complain that they are 'inferior' and 'forgotten', not only in comparison with the white man (TP waitman) or PNG town dwellers, but also in comparison with neighbouring groups. This is a common feeling among those Papua New Guineans who are far from roads, shops, health centres, and governmental offices (cf. Kulick 1992a; Robbins \& Wardlow 2005). ${ }^{2}$

All Awiakay adults are bilingual in Awiakay and Tok Pisin. Within the community, the use of Tok Pisin is confined mainly to situations where it functions as a language of authority, as an attribute of both persons and institutions. One domain in which Tok Pisin is used almost exclusively is Christian services and prayers. Codeswitching between Tok Pisin and Awiakay occurs in public speeches, quarrels, and other situations where speakers of any gender or age want to take an authoritative position in the communicative act. While all children are fluent in Awiakay, they acquire Tok Pisin at a very early age (when they are four or five). They are addressed primarily in Awiakay, whereas Tok Pisin is used for scolding (for a reverse situation see Kulick 1992a: 216-17). Tok Pisin is also often used by the elementary school teacher in the tok ples skul 'vernacular school'. ${ }^{3}$ Although instruction has been irregular since the founding of the local school in 2005, one generation of 'children' (the pupils were aged between seven and twenty) has been taught basic literacy skills in Awiakay and Tok Pisin. Due to the lack of paper and reading materials, these skills are seldom practised in non-school contexts. As a lingua franca, Tok Pisin is associated with the outside world and with the new objects and concepts that those who travel to the town bring back to the village. However, the Awiakay people have not connected the ways of urban Papua New Guineans and development - everything they long forwith Tok Pisin to such an extent that they would consciously or subconsciously increase its use in their everyday speech, in the pattern documented by Kulick 
(1992a) for Gapun, a small village also in the East Sepik Province, where some decades ago people shifted away from addressing their children in their own language. Instead, the Awiakay continue to use their mother tongue as their everyday language, but they readily borrow new terms from Tok Pisin and often adjust them to Awiakay morphology (Hoenigman forthcoming). English also has a peripheral presence in the Awiakay sociolinguistic scene, at least as a focus of broad awareness and idealisation. Many Awiakay say as a matter of course that people in Australia (which is a synonym for the Western world) and educated Papua New Guineans (often called kandukya 'white men', as they live in a state of prosperity like all white people are believed to) speak English. Young people sometimes express a wish to learn the language, saying that they would then be able to travel to Australia. However, this possibility seems so remote that nobody gives it much consideration. Six adult men who went to school in Amboin or Angoram (one of them finished grade twelve, the others grade six or lower) learned English, but they never use it, and even they perceive it as a foreign code. The languages of people's immediate environment are therefore Awiakay and Tok Pisin.

The Awiakay have been nominal Catholics since the 1950s, and during that time have gradually abandoned initiation and other customary rites. However, in the mid-1990s, the Awiakay people wholeheartedly embraced the Catholic charismatic movement, often referred to in this area by the Tok Pisin expression gutpela nius, 'good news'. This movement arrived in the villages of the Amboin Parish (Fig. 1) in December 1994 when a wooden statue of the Virgin Mary was brought there from the provincial capital Wewak (Telban 2008: 229; 2009: 133, 144). ${ }^{4}$ The movement was brought to Kanjimei by three local men who happened to attend a Charismatic seminar in the faraway coastal city of Lae, where they received the gifts of the Holy Spirit: the gifts of healing and speaking in tongues (Hoenigman 2007: 67-70). In exchange for the 'services' of the Holy Spirit, charismatic Christianity has demanded that people break their relationships with bush spirits and ancestral spirits. Both of these categories of spirits were labelled as evil and came to be associated with Satan. ${ }^{5}$ Charismatic prayer meetings and healing sessions are held in Tok Pisin, whose use in the village has thus increased. Although Tok Pisin has been mainly confined to charismatic activities, its influence is also seen in settings in which there is a conflict of power, and it is gradually spreading to other domains of language use.

Coincidentally, just a couple of years after the arrival and uptake of the charismatic movement, the Awiakay learned the value of eaglewood from Indonesian traders who came to Papua New Guinea in search of the precious resin contained within it. $^{6}$ Discovering that their land abounded with it, the Awiakay started trading in eaglewood and getting what they thought was good money. Everyone in Kanjimei interpreted this sudden source of income as God's reward for their involvement in the charismatic movement, a pattern of interpretation consistent with traditional beliefs about good fortune, which was ascribed to people's good relations with the bush spirits. However, charismatic prayer meetings soon became irregular, because 


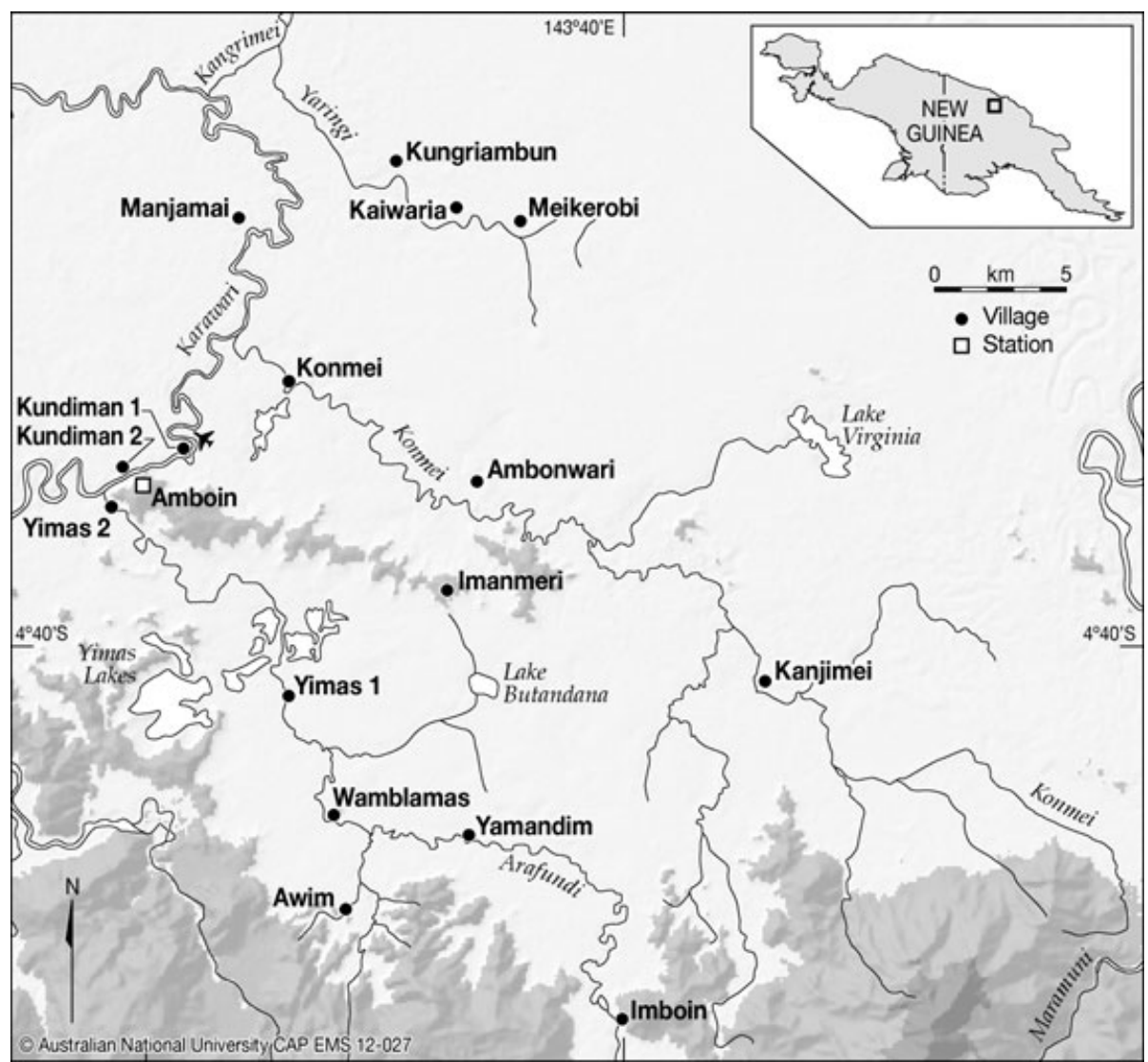

Figure 1 Map of Amboin Parish.

people spent most of their time in the mountains seeking eaglewood. Charismatic activities have become mostly limited to times of adversity, such as sickness and death. In the last few years, the boom in eaglewood trade has declined and the price has dropped, due in part to regulations the PNG government put on its previously uncontrolled export. Emep kolopla, 'sitting well', an expression which the Awiakay interpret as 'a state of prosperity and absence of sickness and death', has not arrived yet. This expression translates into Tok Pisin as gutpela sindaun, and is roughly synonymous with developmen 'development'. People keep praying and waiting for such development (cf. Kulick 1992a: 282), as well as looking for reasons as to why it does not happen.

It was against this background that in late 2009 a discursive event unfolded in Kanjimei, which shook up the sociolinguistic status quo in the village and is likely to have ongoing, if subtle, significance in Awiakay people's ever-shifting linguistic ideologies. We now turn to this event. 


\section{THE SPIRIT-POSSESSION EVENT}

October is a month dedicated to the worship of the Virgin Mary, and in October 2009, a wooden statue of Mama Maria (Tok Pisin for 'Mother Mary') was travelling around the Amboin Parish. ${ }^{7}$ She stopped for two nights in each village. She was carried around by women whom she had 'chosen by herself' by pointing at them with her head. While holding the statue, a woman was believed to be controlled by Mother Mary who channelled herself through the statue and communicated with people through gestures. During her stay in Kanjimei, Mama Maria was believed to 'work' or 'act', that is, to heal, hear people's prayers and perform miracles. People were putting all their hopes and wishes into those two days. The general hope was that Mama would finally acknowledge that Kanjimei, las ples, deserved to get development.

When a group of twenty people from the neighbouring village Ambonwari originally brought the statue to Kanjimei, Mama Maria, while being held by an Ambonwari woman, was dancing around me while I was videorecording, pointing with her head at me and downriver towards Ambonwari. Because this continued for a while and the gestures of the statue were becoming ever more assertive, the Awiakay decided that she was becoming too violent and Yukun and Moyambe, two charismatic leaders, asked me to stop recording. As I put the camera down, the Ambonwari woman who was holding the statue danced away and handed it over to a middle-aged Awiakay woman, Pambaim. As soon as Mama Maria was in Awiakay hands, Yukun came to ask me to turn the camera on again. Later, he and Moyambe explained that it was not Mother Mary, but the jealousy of Ambonwari people that had controlled the statue and caused it to become violent. ${ }^{8}$ When the statue of the Virgin Mary was brought to the church, Moyambe, the prayer leader, used Awiakay hidden talk (Hoenigman forthcoming) to say that Mama could not start 'working' until there were no longer 'other people' in the village. He avoided her name, so that the Ambonwari would not be able to understand what he was saying, and called her tasia, which is Awiakay for 'bush spirit'.

On the second evening of her presence, after the departure of the Ambonwari people, Mama finally started to act. The whole village gathered at a prayer meeting, which started in an ordinary way, with songs and prayers. In the hands of Pambaim and Kasom, the women who were chosen by Mama herself, the statue was 'walking around', 'dancing', 'talking' to people, and 'hearing' their prayers (Fig. 2). At a certain point, Toska Panbok, a woman in her late twenties, became possessed by a spirit. After subsequent discussions in the following weeks, people agreed that it was the spirit of Mother Mary speaking through her, although some had initially been confused, not knowing whether it had been Satan or one of the good spirits: Mama Maria, Jesus, or the Holy Spirit.

In Kanjimei, possession by the Virgin Mary is particularly common during big healing sessions when a person is dying and most of the villagers are present. In these events, people witness multiple events of possession by different Christian figures. $^{9}$ Charismatic leaders in Kanjimei say that during possession, it is easy for the 


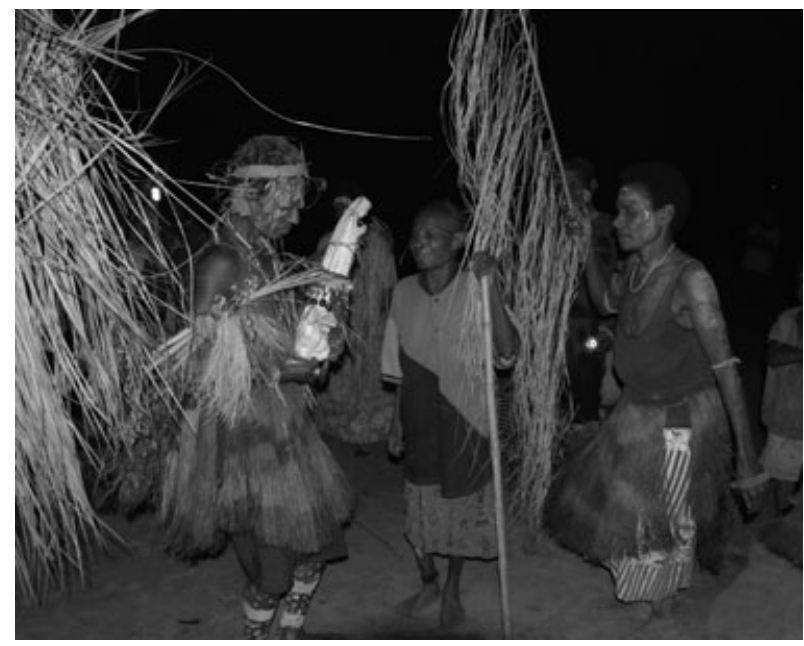

Figure 2 The statue of the Virgin Mary 'dancing' in the hands of Pambaim.

evil spirit (i.e. Satan) to take over and pretend to be one of the good spirits in order to mislead people. That is why the leaders often hold their hands above the possessed person, repeating the word kontrol 'control' in Tok Pisin. As soon as they feel they themselves are not 'in control', i.e. unable to interpret what is happening around them, or do not agree with what is being said or done, people ascribe their confusion to the evil spirit. ${ }^{10}$

Acting through Toska, the spirit of Mama harshly reproached the most important village leaders (Fig. 3). These were the councillor Joseph Aymay, the village magistrate and charismatic leader Geoffrey Yukun, and the main prayer leader Charles Moyambe. They had been the very first Awiakay men to receive the gifts of the Holy Spirit and were the ones who brought charismatic Christianity to the village. They were accused of being idle, not using their gifts properly and thus preventing the 'good spirit' from embracing the village and opening the door to development. What was most intriguing - given that she usually speaks Tok Pisin — was that Mama Maria was speaking Awiakay.

I now turn to a detailed description and analysis of excerpts from this spirit-possession event (which I will sometimes call the 'Mama Maria event'). Video of the first excerpt, showing Toska as the spirit of Mama mocking and scolding village leaders, is available in the online version of this article, which I now invite readers with internet access to view (see Supporting Information, Movie S1).

The excerpt begins with a late night prayer meeting with the statue of Mama Maria. People are moving around, singing and dancing. Most of the time there is singing in the background. Not everyone is paying attention to the unfolding discourse of spirit possession.

The transcript below shows Mama Maria speaking Awiakay while scolding the leaders, in particular Moyambe, the main prayer leader (see also Fig. 4). She used Tok 


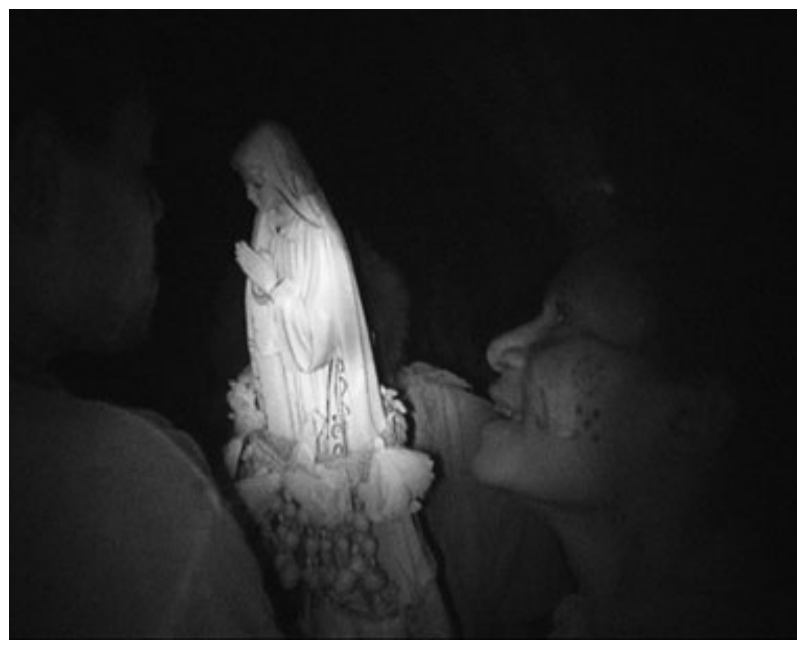

Figure 3 Mama Maria speaking to Joseph Aymay.

Pisin only with common borrowings or when swearing (for which Tok Pisin is considered especially appropriate). Awiakay speech is given in italics; Tok Pisin is italicised and underlined.

Verbatim transcript of 'Mama Maria event' excerpt 1 (FILM 1): Toskal spirit of Mama mocking and scolding village leaders ${ }^{11}$

MOYAMBE [prayer leader]:

$1 \quad$ Tri-tu-wan, say...

Three - two - one, say...

[clapping]

PEOPLE at prayer meeting:

.... Jisas!

MOYAMBE:

Alelu-|

Hallelu-

TOSKA:

| Nogat ia!

No way!

MOYAMBE:

$5 \stackrel{- \text {-ia! }}{-j a h !}$

TOSKA:

$\frac{\text { Nogat! }}{\text { No! }}$ 
MOYAMBE:

Sakias!

Zacchaeus!

TOSKA:

O-o! Ehe-hee [laughs]!

No-no! He-he...

MOYAMBE:

Lazarus, kamaut!

Lazarus, come out!

TOSKA:

10 O-o!

No-no!

MOYAMBE:

Alelu- Jisas! [...]

Hallelu- Jesus!

Husat $i$ karim laif bilong yu?

Who's carrying your life?

SOME PEOPLE / OTHERS:

Jisas! / Mama!

Jesus! / Mama!

TOSKA:

Mae nan tay mundimba Moyambe!

Wait for me first, Moyambe!

15 Moyambe a!

Hey, Moyambe!

Moyambe!

Moyambe!

Mae mupa mae stopimbapa kambanja.

Wait first, stop for a while.

Mae mundimba!

Wait for me!

YONGGNDAM [a woman possessed by the Holy Spirit, a short instance of glossolalia] TOSKA:

Nan- nin tema tema tayan autimbapopalikim.

You- many times I've been communicating [God's talk].

20 Eskius.

Excuse me.

YONGONDAM:

Aunda aka umbundimbem pe umbundimbem endemdimbem pe.

Don't dance without a reason, she says, dance with leaves in your hands, she says. 
D. Hoenigman

Kundainjinge pe, kundainjinge pe.

This has roots, she says, this has roots.

[has meaning]

TOSKA:

Nan tema tema, tema tema iñike.

Many, many times you came.

Nan tema tema, tema tema iñike, tayan popmanim Moyambe?

Many, many times you came, and you made like this, Moyambe?

25 Tayan ton yamanim?

Is that the way you are?

Pes! Pes!

Whack! Whack!

Tema tema tayan yape.

He was like this all the time.

A? Elak pukumanim?

Hah? Can you remember this?

Amba yañaimbukim?

What did I tell you?

30 Pukumanim?

Remember?

Nan tayan kay yamanim?

Will you carry on like this?

[people's explanation: yu bai karim hevi raun olsem? You have troubles [transgressions...]

- how will you carry out God's work?]

Tajan kay yamanim?

Will you carry on like this?

Aunda tayan yaman.

You're just like this.

Pes! Pes!

Whack! Whack!

35 Moyambe!

Moyambe!

Kopon kunjakaninay, longlong mapojan. A?

Your head will break [like a wooden stool or a hand-drum or a ripe pawpaw], you will go mad. Hah?

Longlong maponan, tok tru yañaimbalik.

You will go mad, I'm telling you the truth.

\section{YONGGNDAM:}

Ekanjingom yamblakapepalik.

I'm calling you.

TOSKA:

Tok tru yañaimbalik. Save?

I'm telling you the truth. You know? 


\section{Tingim gut!}

Remember that.

$[\ldots]$

\section{TOSKA:}

Heey, Yukun alay grasman pakan pongoy, sem bilong en!

Heey, Yukun, a self-proclaimed prophet, shame on him!

[...]

Kambanjanda en kopa aka opepla pe, pipia lida stret!

They don't see the path at all, she says, real rubbish leaders!

Plali pekpek lida!

Bloody shitty leaders!

WOMAN:

Tayan paygay.

So she told.

45 Uu! Sem elak!

Uu! Shame!

\section{TOSKA:}

Awiakay a, niy anda ambalik.

You Awiakay lot, I'm leaving.

[goes away]

At this point Toska goes away. However, it is not long before she turns around and comes back again. Provoked by the spirit's accusations, Moyambe starts fighting back, but before continuing with the description of the event, let us take a closer look at some features of the spirit's speech.

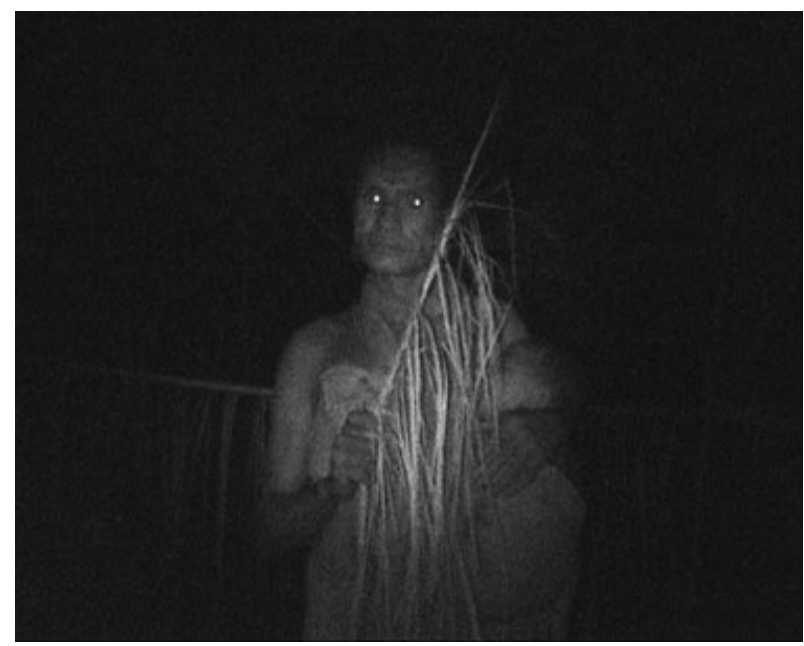

Figure 4 Toska possessed. 


\section{FEATURES OF THE SPIRIT'S SPEECH AND ITS INTERPRETATION}

In the above excerpt from the spirit-possession event Toska (the spirit of Mama) starts by opposing the prayer leader while he is calling out the phrases to which people are expected to respond. When he calls out: 'Zacchaeus!' (line 7), this alludes to Luke 19:1 -10 , and is supposed to provoke other people to call out 'Come down!' ${ }^{2}$ Later (line 9), Moyambe calls: 'Lazarus!', this time alluding to John 11:43, and people are supposed to call with him: 'Come out!'13 These two 'formulae' are employed in all healing sessions and during all important charismatic prayer meetings, at the climax of the event. They index the leader's power and authority. Most Awiakay people do not connect them with the Biblical stories, but they all recognise these calls as powerful words of Jesus. ${ }^{14}$ By laughing at Moyambe when he calls out these important formulae and directly opposing him at the most important part of a prayer meeting (lines 4, 6, 8, 10), the spirit-possessed woman Toska rejects his authority. As people explained later, her laughter and linked expressive acts meant: 'No, you're not acting like Jesus, I'm not going to listen to you!' Considering that she was believed to be uttering the words of Mama Maria, this was a serious attack on Moyambe's credibility as an important prayer leader and a powerful 'big man'.

Throughout the possession event, the spirit uses a number of identifiable linguistic devices, including allusive person reference, rhetorical questions, tropes, and indirection or what I will call 'crypticness'. I turn now to a brief discussion of these features. As we will see later, they are consistent with certain aspects of the Awiakay political ethos, egalitarianism, and gender norms.

The Awiakay generally avoid using names of the powerful and therefore potentially dangerous entities. In most cases within the 'Mama Maria event', references to such entities were made by employing a descriptive term, e.g. 'the one who holds the ground' (1) or a demonstrative pronoun 'this' (2). The examples in the following section are taken from parts of this event that do not appear in the transcripts in this article.

(1) Kunjakanta map mokoyke kalekiay muygaim mae.

'The one who holds the ground [God] is looking now.'

Rhetorical questions are used for a variety of purposes. As one cannot answer them, they are designed to shame (cf. Schieffelin 1990: 87). Following the same pattern as domestic quarrels, where the speaker aims at reproaching and insulting their partner, some of the rhetorical questions in the spirit's speech are used to remind the listeners of the opposite of what the question asks:

(2) Elak tok liklik samtinkim?

'Is this [referring to the power of statue] (just) a little thing?'

This rhetorical question implied: 'This is not a little thing - it is something very important.'

Another type of rhetorical question aims to point at what has gone wrong and thus implicitly to blame those who have let this happen, e.g.: 
(3) Em yet $i$ westim taim, bilong wanem westim taim $i$ stap?

'He's wasting time, why is he doing that?'

The speaker, i.e. the spirit of Mama Maria, is not really interested in why Aymay, the village councillor, who has received the gifts of the Holy Spirit, is wasting time. What her question implies is: 'He shouldn't be wasting time.'

In contrast to public village fights where disputants use rhetorical questions mainly to hold the floor, the spirit does not need to do this. However, rhetorical questions add weight to the spirit's words and further provoke the audience to look for the meaning which (for social reasons) cannot be offered directly.

Another linguistic device that the spirit often employs is tropes, for example, an image of dancing when referring to the careless joy that one feels when one does not hold any resentments or grievances, or is free from accusations of any wrongdoings; or an image of digging out the roots for 'getting to the core of the problem'. Although to an outsider the spirit's speech gives an appearance of being highly metaphorical, these tropes are indigenously recognised (though not necessarily interpreted by everyone in the same way; cf. Rumsey (1986: 288-89); and Merlan \& Rumsey (1991: 108-09).

These two devices, rhetorical questions and tropes, are used also in other Awiakay registers and will thus not be further discussed here. A feature that is characteristic of the spirit's speech and needs some attention, however, is her crypticness. The spirit's messages are not explicit. They require interpretation. In Awiakay, this way of speaking is referred to as wayaym momba, 'obscured talk', which translates into Tok Pisin as kailim tok, and was explained to me in the following way:

Spiritun mokongombongoy, wayaym momba kakayambaluy.

When we're possessed by a spirit, we're using wayaym momba 'obscured talk'.

Momba kopa emep aka koñipaluy.

We do not reveal the true meaning of the talk.

Aunda mokowayapepaluy.

We're just obscuring it.

Tom kele mokotakuakay konda moknamba momba kopa.

Later others will deliberate upon it and find the meaning.

The most significant utterances to the Awiakay are those which-to an outside observer-initially do not seem to make much sense (cf. Tomlinson, this issue). At the same time, these are the ones which give most room for discussion. In the framework of linguistic pragmatics developed by the philosopher of ordinary language, Grice (1975), these utterances are 'insufficiently informative' and the audience is forced to look for a reading that makes sense. Explanations of these cryptic utterances are formed in terms of people's views on the state of affairs in the community and their previously (publicly) unexpressed grievances or accusations. An example of such an utterance is: 
(4) Aymayan amba inayke aka kamba kambat umunak pe unja.

'When Aymay does what, I will dance forcefully, she says.'

Instead of saying explicitly what Aymay should do, this statement provokes people to infer it for themselves. ${ }^{15}$ Everybody in the village knows that Aymay was one of the first three men who received the gifts of the Holy Spirit. People also feel and occasionally say in secret that he is neglecting these gifts, which means that the community cannot benefit from them. The Awiakay have been waiting for development for a long time. When God finally decided to improve their lives and bestowed special powers upon some people, it turned out that, in the general view, those people have proved to be unworthy of the powers which they could be using for the common benefit. Now Mama has come to warn them that they will forever stay 'in the dark', as she herself says, unless they change their lives.

\section{THE ROLE OF GENDER IN THE SPIRIT'S SPEECH}

The spirit's utterances coming from Toska's mouth are characteristically female in Awiakay terms. In scolding the leaders, the spirit provokes them in the same way Awiakay women do when they accuse their husbands of being lazy and not helping them pound sago, which shames a man and normally leads to a fight. She continually repeats her accusations and enhances them with rhetorical questions and insults. Calling the leaders plali pekpek lida (TP) 'bloody shitty leaders' (line 43) was a strong insult. In a society where anything concerning male defecation is as surrounded by taboo as matters connected to female menstruation, scatological insults are in the most offensive category. In this, Mama Maria boldly breaches the norm set by the teachings of the Church and Marian movements which ascribe to her virtues such as silence, obedience, and modesty (Hermkens 2007: 7), qualities that 'constitute the very quintessence of passive female submission' (McLaughlin 1974, quoted in Hermkens 2007: 7). Instead, she speaks and acts like an Awiakay woman. This is in line with Kulick's (1993: 512) description of women in Gapun as 'forceful and belligerent in provoking and sustaining verbal conflict'. If in urban Papua New Guinea the Virgin Mary has become a role model for women, providing them 'with an example how to be a good Christian mother and wife' (Hermkens 2008: 164-65), in Kanjimei it is rather an Awiakay woman that seems to be a model for the image of Mama Maria. Mama Maria is perceived much like the bush spirits to whom people ascribe culturally-recognised gender roles and kinds of conduct (although she is believed to be much more powerful than these spirits).

\section{A BATTLE OF LANGUAGES}

While Aymay and Yukun accepted the spirit's reproach without complaints, Moyambe was convinced that Toska must have been possessed by Satan, who was jealous of his good reputation in the village and so Moyambe started fighting back. (His views about Toska's possession appear in transcript 2 below, in lines 63 and 73.) The 
ensuing verbal fight between him and the spirit becomes a battle of languages: the spirit speaks Awiakay and Moyambe speaks Tok Pisin and English. While Moyambe believes his choice of codes to be a powerful weapon, he is overpowered by the Awiakay-speaking spirit. This became apparent in the following weeks when people reached the verdict that the spirit had, indeed, been Mama Maria.

A film clip of an excerpt of Moyambe's fight with 'Satan' is also available in the online version of this article (see Supporting Information, Movie S2), which the reader is now invited to view. In the transcript below, we can follow the battle of languages visually in the form of the alternating typefaces by which I have represented those languages: Awiakay speech is italicised, Tok Pisin is italicised and underlined, whereas English is italicised and bolded.

\section{Verbatim transcript of 'Mama Maria event' excerpt 2 (FILM 2): Moy- ambe's fight with 'Satan'}

MOYAMBE:

1 Ey! This is my village [vilis]!

Hey! This is my village!

Who $[\mathrm{u}]$ are you?| Who $[\mathrm{u}]$ are you?

Who are you? Who are you?

TOSKA:

-Mokoinba-yañaimbalik kunda. Mokoinba-yañaimbalik.

I'm telling you all to hold onto the roots. I'm telling you all to hold onto them.

MOYAMBE:

Yu husait?

Who are you?

TOSKA:

5 Mokoinba-yañaimbalik.

I'm telling you to hold onto this.

Noy ${ }_{1}$ tayan injiniy. $\left.\right|_{2}$

You $[\mathrm{pl}]$ are like that, in the middle.

MOYAMBE:

$F_{1}$ Yu husait?

Who are you?

$\mathrm{F}_{2}$ Yu husait?

Who are you?

TOSKA:

Tayan embepemba yañaimbalik.

I'm telling you, I will put it like that.

10 Tanan.

Like that. 
D. Hoenigman

MOYAMBE:

Yu husait?

Who are you?

TOSKA:

Kunda mokoimba mae moke kunda elak.

Hold onto this, hold onto these roots.

MOYAMBE:

Yu husait?

Who are you?

TOSKA:

Moke!

Hold [pl]!

MOYAMBE [calling Jesus]:

15 Come back! Come back! Come back!

Come back! [x3]

I tell you! Come back!

I'm telling you! Come back!

Come ... back!

Come ... back!

$[\ldots]$

Move out! (x2)

Move out!

[...]

Kontrol! Eskius mi, kontrol!

Control! Excuse me, control!

20 Kontrol! (x3)

Control!

Kontrol kam insait!

Control, come inside!

Kam insait! (x3)

Come inside!

Kam insait!

Come inside!

Kam insait! (x3)

Come inside!

25 Mi no liklik manki, harim, a? A?

I'm not a little boy, you hear me? Hah?

I'm a big man in this village!

I'm a big man in this village!

I can belt you off?

I can belt you up! 
TOSKA:

Bihain bai yu kirap nogut.

Later you'll be surprised.

MOYAMBE:

Hey!

Hey!

30 Hey, I can belt you up!

Hey, I can belt you up!

Get out! (x5)

Get out!

Hey! Ha! Hey! Ha! Who are you?

Hey - ha! Hey - ha! Who are you?

Don't play with me! Ha!

Don't play with me! Ha!

Don't play with me! Ha!

Don't play with me! Ha!

35 Who are you?

Who are you?

Yu husait? Ha?

Who are you? Hah?

Get from this gate, hey!

Get [out] from this gathering, hey!

I don't like - I don't want to see you here!

I don't like - I don't want to see you here!

This is not your village, | this is my home! Hey!

This is not your village, this is my home! Hey!

TOSKA:

$40 \quad$ - [...] amunga pakapap umunakim?

$[\ldots]$ how will I carry and dance?

MOYAMBE:

Come back!

Come back!

Set your mind!

Set your mind!

Setim tinktink bilong yu, a.

Set your mind, hah.

Setim tinktink!

Set your thoughts!

45 I want...

I want... 
D. Hoenigman

Jisas!

Jesus!

Kambek!

Come back!

Kambek! (x3)

Come back!

Yupela tu noken sindaun natink, setim!

You [pl] can't just sit like that, set [your thoughts]!

50 Setim, setim keset bilong yupela!

Set, ready your cassette!

Putim on!

Put it on!

Yu lukim olsem wanpela vidio o wanpela drama.

You're watching as if this was a video or a performance.

Baimbai lus ia, bai yu lus!

You will stray from the path!

Harim, a? Em i laik salensim mi!

You hear that, hah? He's challenging me!

55 Mi dai, yupela tu bai indai.

If I die, you will also die.

Harim tok, $a$ ?

You hear me?

MEN:

$\frac{\text { Yes. }}{\text { Yes. }}$

MOYAMBE:

$\mathrm{Ha}$ ?

Hah?

MEN:

$\frac{\text { Yes. }}{\text { Yes. }}$

60 Mi dai, bai yupela olgeta inap seif, $a$ ?

You think you will all be safe if I die?

YONGGONDAM:

Mipela olgeta bai dai.

We will all die.

MOYAMBE:

Bai yupela seif, a?

Will you be safe? 
Em $i$ wokim jeles ia, yu harim tok? A?

He's just being jealous, you hear? Hah?

Mi indai bai yupela olgeta kuk!

If I die you'll all burn!

65 Harim, $a$ ?

You hear?

Seten em $i$ komplein long fran-men!

Satan's complaining about the front man!

Hey, franmen, ia, Aleluja...

Hey, frontman, yeah, Hallelujah...

Fran men! (x4)

Front man!

Hey! (x3)

Hey!

70 Fran men! (x2)

Front man!

YUKUN:

- Yu wan-wan mas opim spirit na putim iau stret ... putim iau stret. Putim iau gut. Each of you must open your spirit and listen attentively ... listen attentively. Listen carefully.

\section{MOYAMBE:}

Satan is jealous to me!

Satan's jealous of me!

Fran men! (x2)

Front man!

75 Harim, a, noy setimbape nokomgoy keset.

Listen, ready your cassettes.

Tenkyu tru Mama kam na lukim yumi.

Thank goodness Mama came to see us.

Klostu tru kamap olsem disasta bilong Aitape, a?

We were about to experience a disaster like the one in Aitape.

\section{YUKUN:}

Trupela...

True...

MOYAMBE:

Aitape pisip yakalakay...

Almost like Aitape...

80 Lukluk gut! A? Lukluk gut!

Be careful, right? Be careful.

[...] 


\section{TOSKA:}

An kuyanja kambanjagay pondimbon.

He [Moyambe] thinks he's a little child.

Taygia yakngaiñinayke kopa mokopep kendenda.

When the spirit turns up again, I will tell you its message.

MOYAMBE:

Yu traim baimbai yu lukim. Hey!

Try and you'll see. Hey!

TOSKA:

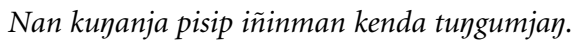

You will come back to me like a child.

MOYAMBE:

85 Laki, laki, laki, ia!

Lucky, lucky, lucky, yeah!

[laughing]

Mi lap long yu ia, aleluia, aleluia!

I'm laughing at you, Hallelujah, Hallelujah!

\section{YOŅGONDAM:}

God bai win.

God will win.

TOSKA:

Mae keyam nayga.

Let him laugh first.

MOYAMBE:

You cannot, | you cannot distroim mi.

You cannot, you cannot destroy me!

YUKUN:

90 - Olgeta setim op na stap.

Everybody set off and stay.

MOYAMBE:

You cannot, you cannot distroim mi.

You cannot, you cannot destroy me.

As the main prayer leader in Kanjimei, Moyambe had been convinced that the whole community appreciated and supported his 'work for God'. Moreover, Moyambe believed that God was happy with him as a loyal servant and he had often publicly emphasised as much. He frequently sought to heighten his status (TP apim nem bilong em yet) by boasting to the community that it was with his help that God was doing favours for them. While occasional boasting can help a man on the way to being recognised as a 'big man', such a man ultimately achieves respect in the community 
through his actions that result in tangible well-being for everyone. ${ }^{16}$ In an egalitarian society, it is all too easy to cross the boundary between the acceptable and the unacceptable, in which case the boaster's status will need to be lowered. This, however, cannot be done by an individual, as his/her action would be seen as highly immoral. A person can initiate a dispute with another-even a leader-who has somehow violated that person, their relatives or their property (and disputing for these reasons is even encouraged), but one cannot oppose a leader for bad leadership. While people do enact such opposition by gossiping, tui momba 'illegal talk' or TP tok baksait 'gossip', 'talking behind people's backs about them' is considered to be a major transgression.

In his discussion of gossip on Nukulaelae Atoll, Tuvalu, Besnier (2009) shows how gossip enables people to enact or challenge power structures, but he adds that it is 'often regarded as a reprehensible activity to be avoided or feared' (2009: 13). However, among the Awiakay, spirit-possession has the effect of making criticism possible: discussing a spirit's words is no longer considered gossip or public criticism, because these words have a different status from those of human speakers. This point is central to an understanding of the significance of the spirit's utterances and their reception by the community.

\section{THE COMMUNITY'S INTERPRETATION OF THE VERBAL BATTLE}

While Moyambe believed that he was using the most powerful verbal weapons-Tok Pisin and English—-his choice of code, as well as his actions, actually turned against him. People later agreed that he was not 'shooting' at Satan, but at Mother Mary, and so his abuse of his opponent damaged his reputation. What actually mattered in this case was not whether Moyambe would manage to verbally overpower the spirit, but the fact that through this fight, the spirit enabled people in the community to openly discuss a delicate matter, that is their critical views about their leaders. Although Mama Maria spoke as if she was quarrelling with Moyambe and scolding other leaders, her targetted overhearers, in the sense developed by Goffman (1981) and Levinson (1983), were actually other members of Awiakay society, whom she addressed by using Awiakay and the ways of speaking that people are familiar with from other contexts.

About two weeks after this event, Noah Wayk, a man in his early forties, died 'without a reason'. Unless someone dies in an accident, or through illness or from snakebite, people say aunda we 'he/she died just like that' i.e. 'without a reason' and ascribe the person's death to their own or their close relative's transgressions. Seven months earlier, after three successive deaths in the village, the Awiakay made a contract with God, which was supposed to stop deaths. Wayk was the first person who died after that, and one of the explanations people put forward was that by chasing off Mama Maria as if she were Satan, Moyambe had broken the community's contract with God and opened the door to death again.

One day, when some Awiakay and I were sitting on the veranda of my house, Yakame, Moyambe's mother-in-law, walked past as if in a trance, oblivious to everything around her. She was possessed by a spirit who was announcing more deaths in the village: $\underline{Y u}$ 
tanim baksait long God, em bai salim sanguma o spirit nogut long kilim yu. 'You turned your back on God. He will send an assault sorcerer or evil spirit to kill you.' Everyone around me agreed that the spirit was speaking of Moyambe. A few weeks later, his child became sick, which was seen as yet another confirmation that he had been wrong.

\section{TOSKA'S RESPONSIBILITY AND POWER RELATIONS}

Several parallels can usefully be drawn between Du Bois's (1993) discussion of intentionality and responsibility in divination and issues of personal expressive agency in Awiakay spirit speech. As Du Bois puts it concerning language uttered in trance, 'the utterer of the shifter pronoun is "speaking involuntarily or nonintentionally" - and thus, paradoxically, in another sense is not "speaking" if we understand by this acting as a responsible speech actor' (1993: 53). While Du Bois argues that divination (or in our case spirit speech) works by suppressing speaker intentionality, Keane (1997: 57) suggests that we should rather be thinking in more wide-ranging terms of the ascription of intentions. He adds that 'what $\mathrm{Du}$ Bois takes to be the suppression of individual intentionality can also be described as an expansion of the presupposed speaking subject beyond the level of the individual' (1997: 57).

In keeping with Keane's point, in Awiakay people's view, a person who is possessed by a spirit becomes a spirit. Such a person's words and actions are not attributed to them, but to the entity who is speaking through them, so they will not be judged for what they say or do during possession. ${ }^{17}$

Building on Goffman's (1981) classification of participant roles, we can say that the spirit is both the principal, who bears responsibility for what is said and done (but not for the meaning), and the author who formulates the actual words and actions. Toska is merely the animator, one who utters these words. Moyambe and other reproached leaders are proximal addressees, whereas the roles of the target, to whom the words are ultimately directed, and the overhearer merge into one, because everybody is supposed to hear Mama's complaints. The principal-author and the animator occupy the same physical body, but are not perceived by the Awiakay as the same entity (cf. Keane 1997: 58). This is why Moyambe has never expressed any reproach towards Toska for attacking him, but rather did so towards the spirit, in his opinion Satan, who was speaking through her. If she were acting as herself, Toska, as Moyambe's classificatory sister (MZD), would be expected to support and not attack her brother. Yet nobody in the community complained about her 'misconduct', because it was clear to everyone that she was possessed by a spirit. It was because of this split between the author and animator roles that her words had power and authority. ${ }^{18}$

A Christian spirit is a higher authority than a village leader. Mother Mary is therefore entitled to criticise the leaders whom she has appointed by herself, as she says later in the argument, just before Moyambe starts fighting back: 


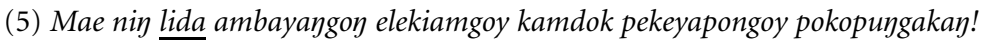

I appointed them all leaders, but now the cloud has sat upon them and I have to destroy it.

Another dimension of the 'Mama Maria event', which I have already briefly commented on, is the power relations inherent in the battle of languages. Spirits (bush, ancestral or Christian) are more powerful than people, but people have ways of dealing with them. It is important to know which entities are more powerful than others, so that one can call on the more powerful ones for help when needed. Christian entities (God, Jesus, Holy Spirit, and Mother Mary) are believed to be able to overpower Satan, whose name is often used as a synonym for all harmful spirits.

When it comes to the hierarchy of languages, Awiakay is not perceived as a language of power. Its speakers (whether Awiakay people or local spirits) do not possess all the desirable goods that they associate with speakers of Tok Pisin (and English) in general. As noted in the Introduction, Christian prayers and services, as well as Christian spirits and PNG town dwellers are all associated with Tok Pisin. Moreover, Tok Pisin is associated with the authority of governmental institutions. Although people know that the world outside PNG, which is perceived as even more powerful, speaks English, very few in the village can speak any English at all, so the language of authority in their immediate world is Tok Pisin. However, Awiakay is not completely powerless: its implicit potency lies in the fact that it gives its speakers a feeling of safety and intimacy. People tend to resort to Awiakay whenever they feel threatened by the unfamiliar, whether in the form of people or places (Hoenigman forthcoming). Awiakay is an indispensable tool for hiding one's intentions (Hoenigman forthcoming) and misleading the enemy, as well as for insulting and challenging others (cf. Kulick 1993). This can cast light on the paradoxical situation of Awiakay 'winning' over the generally more powerful codes, Tok Pisin and English, which occurred during Moyambe's confrontation with the spirit. ${ }^{19}$

\section{CONCLUSION}

Spirit possession in itself is not a new phenomenon in Awiakay society. While other ways of communicating with ancestral and bush spirits were common in the past, possession by Christian spirits has come into practice since the uptake of the Catholic charismatic movement in the mid-1990s. What made the spirit-possession event discussed in this article unprecedented was the length of possession (unlike late-night spirit messages which last no more than ten minutes, this possession went on for about two hours with some short pauses in between), the fact that the spirit was interacting with people (although not paying much attention to what other people said, the spirit was commenting on Moyambe's actions and words), and the fact that a Christian spirit was speaking Awiakay. While unprecedented in these respects, the whole event took place largely within the terms of established linguistic ideologies and wider socio-cultural frameworks, albeit within a context of cultural change and intercultural articulation. 
One relevant set of established understandings were those held by the Awiakay people about the nature of spirits and their relationships with human beings, and about the nature of spirit possession, namely, that it is possible for a spirit to speak through the mouth of a human being.

Another relevant set of understandings concerned the status of the local Awiakay language in relation to the lingua franca Tok Pisin and a foreign, yet powerful code, English. This is revealed in the speakers' choices of codes, which vary depending on the targeted overhearers. Consistent with this, we can see Awiakay as an insider language. Throughout this event, Awiakay is chosen when the speaker aims at agreement with the targetted overhearers against an 'outsider', e.g. Moyambe speaking to Awiakay people in the church when he did not want the Ambonwari to understand the insiders' secrets, or the spirit speaking through Toska when the targetted overhearers were other Awiakay people rather than the leaders who were being reproached. It was up to the people to give meaning to the spirit's words and it was their discussions and conclusion that lowered Moyambe's, Aymay's, and Yukun's status. In this case the leaders were the 'outsiders', as their acts did not comply with the expectations of the society. Consistent with the established language ideology, Tok Pisin is chosen as a language of authority. English, which in this event unexpectedly enters the Awiakay scene, is only used when fighting with the spirit.

A third relevant set of established understandings was people's attitudes towards the present economic and religious situation. Since the economic prosperity and consequent leisurely lifestyle, which the Awiakay had been hoping to achieve through their adherence to the charismatic movement, did not arrive, somebody had to be blamed. Those blamed were the village leaders who, despite doing what is otherwise perceived as 'community service', did not follow the socially appropriate mode of conduct: Moyambe and Yukun had been boasting too much, whereas Aymay had not sufficiently acted in his calling.

It is on the basis of these established understandings in Awiakay society that we can interpret the 'Mama Maria event', which marked a new development in public criticism. This otherwise transgressive practice became publicly acceptable through spirit possession. People's disappointment is uttered through the mouth of a woman whose indirect, at times cryptic speech and otherwise inappropriate conduct are ascribed to Mama Maria, a powerful divine source (cf. Keane 1997: 57; Stasch 2011:164). Because the community attributes authorship of the words to the divinity rather than the woman, her contentious statements are not only tolerated, but taken seriously. It is the split between the roles of the author and the animator of the speech that gives the spirit's words power and authority. The cryptic indirection of the utterances coming out of Toska's mouth is an index of their divinity, which makes Toska (the spirit) a trusted speaker (cf. Keane 1997: 57; Robbins 2001; Tomlinson, this issue) and the listeners' trust gives power to her words. But in keeping with what has been found in other Melanesian locales (Robbins 2001; Schieffelin 2008), the responsibility for their meaning lies with the listeners, the people of Kanjimei, who deliberated upon it in the weeks and months that followed the event. 


\section{ACKNOWLEDGEMENTS}

This article was written during my $\mathrm{PhD}$ candidature at the Australian National University. Most of the material used in it was collected during my 2008-2009 fieldtrip to Kanjimei, which was supported by the Department of Anthropology, then Research School of Pacific and Asian Studies, and assisted by the Marie Reay Prize. An earlier version was presented at the ANU 60 years of Anthropology conference. I thank Alan Rumsey for inviting me to present in the panel on Interlanguage and Intercultural Articulations in the Asia-Pacific and warmly acknowledge him and Rupert Stasch for their extensive and insightful comments on various drafts, which greatly improved the current article. I am also grateful to Bethwyn Evans, Nick Evans, Andrew Pawley, Bambi Schieffelin and Borut Telban for their invaluable comments on earlier versions, and to Robert Attenborough and Robin Hide for their careful readings. Many thanks to Aung Si for his untiring help in polishing my English translations of the transcripts. The article has also greatly benefitted from the insights gained in discussions with Alan Rumsey, Gary Kildea and Pip Deveson who have at various stages sat with me and watched the subtitled footage of the entire event discussed here. Warmest thanks to Gary and Pip for being my guiding spirits in filmmaking. My greatest debt, however, lies with the Awiakay people for sharing their lifeworld with me.

Please send correspondence to Darja Hoenigman: darja.hoenigman@anu.edu.au

\section{NOTES}

1 In the present article, Tok Pisin speech will be differentiated from Awiakay vernacular speech by underlining, and sometimes by the abbreviation 'TP'.

2 Bambi Schieffelin (personal communication, 7 Jan 2012) reports that Bosavi people of Southern Highlands Province in PNG also thought they were 'the last ones to hear the Word', because this is what the missionaries had told them. The volume edited by Robbins and Wardlow (2005) brings together papers discussing rural Papua New Guineans describing themselves as the last place, linked to the sense of humiliation and lack or longing for development (see also Sahlins 1992). Papua New Guineans who have access to the Internet even post on internet forums that they are the 'last place' in PNG, hoping to persuade the politicians to take better care of them (cf. PNG Politics Forum).

3 The first three years of education in Papua New Guinea are referred to in Tok Pisin as tok ples $\underline{s k u l}$ 'vernacular-language school' and are meant to prepare a child for entry into Primary school at Grade three, which is supposed to bridge the gap between the vernacular-language education and subsequent English education.

4 Amboin Parish (Figure 1) comprises 16 villages of the Amboin Subdistrict. Amboin itself, however, consists of only a station with an aid post, a school, a tourist lodge, the parish church and a priest's house. The priest, a Polish missionary Piotrek Waśko, travels around the two parishes he is in charge of, Amboin and Chambri, and visits each village once or sometimes twice every two months.

5 Charismatic movements in various Christian denominations throughout New Guinea are commonly characterised by a demand for a radical break with tradition, and therefore with the 
communities' past relationships with bush spirits and ancestral spirits, who are now labelled as bad and blamed for illness, misfortune, and lack of development (cf. Telban 2008: 230; 2009 regarding the Catholic charismatic movement in Ambonwari; Eves 2010 on Pentecostalism among the Lelet of New Ireland and Robbins 2007: 128 on the Baptist Urapmin).

6 Eaglewood, also known as agarwood (Gyrinops ledermannii) or Tok Pisin garu, is known for a fragrant resin produced as the tree's response to injury, and has great commercial value, particularly in the Middle East and Asia (Gunn et al. 2004: 1). Papua New Guinea is believed to have the world's last remaining stock of mature eaglewood trees in the wild. There was a big boom in garu business in early 2000s when foreign traders were regularly coming to remote areas in the Sepik region to buy eaglewood which people harvested in the mountains (Gyrinops grows at altitudes between 70 and $850 \mathrm{~m}$ above sea level). For more on the beginning of eaglewood trade in Kanjimei see Hoenigman (2007: 106-7). For more on eaglewood in general see Momberg et al. (2000) or Sekretariat Keadilan dan Perdamaian (2004).

7 My description of the statue as 'travelling', and as an animate actor, is meant to reflect Awiakay patterns of talk, which rarely mentioned that there were people carrying the statue.

8 Because I had stayed in Ambonwari during my first two visits to the region in 1998 and 2001 before later making Kanjimei (the home of Awiakay people) my main research site, the Ambonwari maintained a belief that I belonged to them and not to the Awiakay. My presence in Kanjimei has thus been a source of ongoing complaints and jealousy since the beginning of my fieldwork in the village.

9 While ascribing powers to a statue of the Virgin Mary is common among other Catholics in PNG (Hermkens 2007), possession by her spirit is not. Most of the literature on Pentecostalcharismatic Christianity in Melanesia reports on (often female) possession by the Holy Spirit (Robbins 2004a,b, 2007; Telban 2008, 2009), but not possession by other Christian figures. One would expect possession by the Virgin Mary to occur among the Catholic charismatics; however, it seems that it might be a feature of the Karawari area (the neighbouring Ambonwari claim to be possessed by Holy Spirit and the Virgin Mary during prayer meetings; Daniela Vávrová, personal communication 2 Jan. 2012).

10 Cf. Robbins (2007) regarding Urapmin people's deliberations over whether the Spirit women were communicating the Holy Spirit's will or that of evil spirits.

11 Transcription conventions followed in this article:

SPEAKERS'NAMES in capital letters, each in a full line preceding the speaker's first words

1 line numbers

Awiakay

Tok Pisin

\section{English}

[background information or other interpolations]

interlinear glosses

[clarification of translation]

| overlapping speech - the entrance point of another utterance (transcribed below)

F marks the begining of the utterance which overlaps with the previously started one (its entrance point marked by $\mid$ )

12 Luke 19:1-10 narrates how Zacchaeus, a tax collector of short stature, wanted to see Jesus and so climbed a fig tree to have a better view over the crowd. When Jesus approached, he looked up into the tree and called him down. (The rest of the story is not important for the Awiakay.)

13 John 11:43 is a story about Lazarus, who was dead for four days when Jesus called him out of the grave and brought him back to life. 
14 When I asked several men and women what these words meant, some said that Lazarus was another name for Satan, others said that both Lazarus and Zacchaeus were names of evil spirits which Jesus was driving away by calling out to them, and yet others said that only the leaders know the meaning of these words. There is a song in Tok Pisin which children often sing, with the lyric Sakias, o, yu no longpela man. Yu go antap long diwai long lukim Jisas. 'Zacchaeus, oh, you were not a tall man. You climbed a tree to see Jesus'. Interestingly, though, most people do not connect the words of the well-known song with the ritual callout of charismatic activities. Only the few literate men connected the calls with reference to the Bible.

15 Similarly, Rumsey (1986: 288-9) and Merlan \& Rumsey (1991: 108-9) report for ung eke 'bent speech' (indigenously recognised tropes which occur in various $\mathrm{Ku}$ Waru registers) that while the speaker might intend one meaning, the listeners, who interpret the speech, do not necessarily arrive at the same one.

16 As elsewhere in the Sepik, the Awiakay followed a big-man type of social structure. Only an initiated married man who was a strong warrior, good hunter and a skilled orator had a chance to be called kandey 'big man'. Important decisions in the community were normally reached together with other big men. Nowadays, the category 'big man' is applied even to certain younger men who hold power and respect because they contribute to the community in their role of village teacher or Christian leader, or through possessing an outboard motor they can lend to others to travel to town. In Kanjimei, bigmanship and Christianity are therefore compatible, whereas they are in a problematic relation in Urapmin (cf. Robbins 2004a).

17 Telban (1998: 193) discusses a case from the past when several Ambonwari men killed a woman from a neighbouring village when she approached a men's house. They captured her and clubbed her to death with the snout of a carved spirit crocodile. The men, however, were not held responsible for their actions, as they said that spirit crocodiles were acting through them. In contrast, Bambi Schieffelin (personal communication 7 Jan. 2012) reports that in Bosavi the mediums channel the spirit voices, so that the medium has no responsibility for the utterances, but they are not seen as becoming a spirit, just carrying the voice.

18 This supports Keane's (1997: 59) observation that '[d]istinctions among participant roles can have political consequences.' Lawless (1988) argues that Pentecostal women in patriarchal communities can exert influence that would not be available to them were they to claim full responsibility for their words.

19 Note that this kind of spirit possession in which the possessed person (usually - but not necessarily - a woman) triggers public discussions about delicate village matters, occasionally takes place late at night or at least when there is not much noise in the village. The person usually walks along a village and not everyone hears everything, but people quickly compare notes and interpret what was said. Such spirit messages, however, are much shorter than the one discussed above, and the spirits tend to speak Tok Pisin. Besides, the spirit rarely communicates with people, but rather communicates messages to them.

\section{REFERENCES}

PNG Politics Forum: Lufa las ples long png . Accessed 20 Dec 2011. URL http://www.network54.com/ Forum/159830/thread/1180335535/last-1180582554/Lufa+las+ples+long+png

Besnier, N. 2009. Gossip and the Everyday Production of Politics. Honolulu: University of Hawai'i Press.

Du Bois, J. W. 1993. Meaning without intention: Lessons from divination. In J. H. Hill, J. T. Irvine (eds) Responsibility and Evidence in Oral Discourse, pp. 48-71. Cambridge: Cambridge University Press. 
Duranti, A. 1992. Intentions, self and responsibility: An essay in Samoan ethnopragmatics. In J. H. Hill, J. T. Irvine (eds) Responsibility and Evidence in Oral Discourse, pp. 24-47. Cambridge: Cambridge University Press.

Eves, R. 2010. 'In God's hands': Pentecostal Christianity, morality and illness in a Melanesian society. Journal of the Royal Anthropological Institute 16: 496-514.

Goffman, E. 1981. Forms of Talk. Oxford: Blackwell.

Grice, P. H. 1975. Logic and conversation. In P. Cole, J. L. Morgan (eds) Syntax and Semantics, Volume 3: Speech Acts, pp. 41-58. New York: Academic Press.

Gunn, B. V., P. Stevens, M. Singadan, L. Sunari, P. Chatterton 2004. Eaglewood in Papua New Guinea. Resource Management in Asia-Pacific Working Paper No. 51. Canberra: Resource Management in Asia-Pacific Program, Research School of Pacific and Asian Studies, The Australian National University.

Hermkens, A. 2007. The power of Mary in Papua New Guinea. Anthropology Today 23: 4-8.

Hermkens, A. 2008. Josephine's journey: Gender-based violence and Marian devotion in urban Papua New Guinea. Oceania 78(2): 151-67.

Hoenigman, D. 2007. Language and Myth in Kanjimei, East Sepik Province, Papua New Guinea. MA Thesis, Ljubljana Graduate School of Humanities, Institutum Studiorum Humanitatis, Slovenia.

Hoenigman, D. forthcoming. From mountain talk to hidden talk: Continuity and change in Awaiaky registers. In N. Evans, M. Klamer (eds) Language Documentation \& Conservation Special Publication. Melanesian Languages on the Edge of Asia: Challenges for the 21st Century.

Keane, W. 1997. Religious language. Annual Review of Anthropology 26: 47-71.

Kulick, D. 1992a. Language Shift and Cultural Reproduction: Socialization, Self and Syncretism in a Papua New Guinea Village. Cambridge: Cambridge University Press.

Kulick, D. 1992b. Anger, gender, language shift and the politics of revelation in a Papua New Guinean Village. In P. Kroskrity, B. Schieffelin, K. Woolard (eds) Language Ideologies. Special issue of Pragmatics 2 (3): 281-96.

Kulick, D. 1993. Speaking as a woman: Structure and gender in domestic arguments in a New Guinea village. Cultural Anthropology 8: 510-41.

Lawless, E. J. 1988. Handmaidens of the Lord: Pentecostal Women Preachers and Traditional Religion. Philadelphia: University of Pennsylvania Press.

Levinson, S. C. 1983. Pragmatics. Cambridge: Cambridge University Press.

Makihara, M., B. B. Shieffelin (eds) 2007. Consequences of Contact: Language Ideologies and Sociocultural Transformations in Pacific Societies. Oxford: Oxford University Press.

Merlan, F., A. Rumsey 1986. A marriage dispute in the Nebilyer Valley, Western Highlands Province, Papua New Guinea. Pacific Linguistics Series A, 74: 69-180.

Merlan, F., A. Rumsey 1991. Ku Waru: Language and Segmentary Politics in the Western Nebilyer Valley, Papua New Guinea. Cambridge: Cambridge University Press.

Momberg, F., R. Puri, T. Jessup 2000. Exploitation of gaharu, and forest conservation efforts in the Kayan Mentarang National Park, East Kalimantan, Indonesia. In C. Zerner (ed.) People, Plants, and Justice: The Politics of Nature Conservation, pp. 259-84. New York: Columbia University Press.

Robbins, J. 2001. God is nothing but talk: Modernity, language and prayer in a Papua New Guinea society. American Anthropologist 103: 901-12.

Robbins, J. 2004a. Becoming Sinners: Christianity and Moral Torment in a Papua New Guinea Society. Berkeley: University of California Press.

Robbins, J. 2004b. The globalisation of Pentecostal and charismatic Christianity. Annual Review of Anthropology 33: 117-43.

Robbins, J. 2007. You can't talk behind the Holy Spirit's back: Christianity and changing language ideologies in a Papua New Guinea Society. In M. Makihara, B. B. Shieffelin (eds) Consequences of Contact: Language Ideologies and Sociocultural Transformations in Pacific Societies, pp. 125-39. Oxford: Oxford University Press.

Robbins, J., H. Wardlow (eds) 2005. The Making of Global and Local Modernities in Melanesia: Humiliation, Transformation, and the Nature of Cultural Change. Aldershot, Hampshire, UK: Ashgate Press.

Rumsey, A. 1986. Oratory and the politics of metaphor in the New Guinea Highlands. In T. Threadgold, E. A. Grosz, G. Kress, M. A. K. Halliday (eds) Language, Semiotics, Ideology, pp. 238-96. Sydney: Sydney Association for Studies in Society and Culture.

Rumsey, A. 1990. Wording, meaning and linguistic ideology. American Anthropologist 92: 346-61. 
Sahlins, M. 1992. The economics of develop-man in the Pacific. Res 21: 13-25.

Schieffelin, B. B. 1990. The Give and Take of Everyday Life: Language Socialization of Kaluli Children. Cambridge: Cambridge University Press.

Schieffelin, B. B. 2008. Speaking only your own mind: Reflections on talk, gossip and intentionality in Bosavi. In A. Rumsey, J. Robbins (eds) Anthropology and the Opacity of Other Minds. Anthropological Quarterly 81: 431-42.

Sekretariat Keadilan dan Perdamaian, Keuskupan Agung Merauke. 2004. Bisnis Gaharu dan Dampaknya Terhadap Kehidupan Orang Awyu dan Wiyagar di Distrik Assue, Kabupaten Mappi - Papua Selatan [The Gaharu Business and Its Impact on the Lives of Awyu and Wiyagar People in Assue District, Mappi Regency, South Papua]. Merauke: Office of Justice and Peace, Archdiocese of Merauke. Downloaded from http://www.hampapua.org/skp/indexe.html.

Silverstein, M. 1979. Language structure and linguistic ideology. In P. R. Clyne, W. F. Hanks, C. L. Hofbauer (eds) The Elements: A Parasession on Linguistic Units and Levels, pp. 193-247. Chicago: Chicago Linguistic Society.

Stasch, R. 2011. Ritual and oratory revisited. Annual Review of Anthropology 40: 159-74.

Telban, B. 1998. Dancing Through Time: A Sepik Cosmology. Oxford: Oxford University Press.

Telban, B. 2008. The poetics of the crocodile: Changing cultural perspectives in Ambonwari. Oceania 78: 217-35.

Telban, B. 2009. A struggle with spirits: Hierarchy, rituals and charismatic movement in a Sepik community. In P. J. Stewart, A. Strathern (eds) Religious and Ritual Change: Cosmologies and Histories, pp. 133-58. Durham, N.C.: Carolina Academic Press.

Woolard, K. A., B. B. Schieffelin 1994. Language ideology. Annual Review of Anthropology 23: 55-82.

\section{SUPPORTING INFORMATION}

Additional supporting information may be found in the online version of this article:

Movie S1. Toska/spirit of Mama mocking and scolding village leaders.

Movie S2. Moyambe’s fight with 'Satan'. 